ISSN 0103-5150

Fisioter. Mov., Curitiba, v. 28, n. 4, p. 823-835, Oct./Dec. 2015

Licenciado sob uma Licença Creative Commons

DOI: http://dx.doi.org.10.1590/0103-5150.028.004.AR01

\title{
Virtual and augmented reality technologies in Human Performance: a review
}

\author{
Tecnologias com realidades virtual e aumentada \\ no Desempenho Humano: uma revisão
}

\author{
Tânia Brusque Crocetta ${ }^{[a][c]}$, Sandra Rogéria de Oliveira ${ }^{[b]}$, Carla Maria de Liz ${ }^{[a]}$, \\ Alexandro Andrade ${ }^{[a] *}$ \\ [a] Universidade do Estado de Santa Catarina (UDESC), Florianópolis, SC, Brazil \\ [b] Universidade do Oeste de Santa Catarina (UNOESC), Chapecó, SC, Brazil \\ [c] Escola de Medicina do ABC, Santo André, SP, Brazil
}

\begin{abstract}
Introduction: Today's society is influenced by Information and Communication Technologies. Toys that were once built by hand have been reinterpreted and have become highly commercialized products. In this context, games using Augmented Reality (AR) and Virtual Reality (VR) technologies are present in the everyday lives of children, youth and adults. Objective: To investigate how Physical Education professionals in Brazil have been making use of AR and VR games to benefit their work. Materials and methods: We only included studies that addressed exercise or physical activity using AR or VR games. We searched the databases of Virtual Health Library (VHL) and Scientific Electronic Library Online (SciELO), using the words augmented reality, virtual reality, exergames, Wii and serious games. Results: Nineteen articles were included in the systematic review. The most frequently used device was the Nintendo ${ }^{\circledR}$ Wii, with over 25 different
\end{abstract}

* TBC: tania.crocetta@udesc.br SR0: sandra.oliveira@unoesc.edu.br CML: carla.maria.liz@gmail.com

AA: alexandro.andrade@udesc.br 
kinds of games. With regard to the subjects of the studies, four studies were conducted with healthy individuals (mean $=65.7$ ), three with patients with Parkinson's disease (mean $=18.0$ ), three with elderly women (mean $=7.7$ ) and two with patients with stroke injury (mean $=6.0$ ). Conclusion: Many physical therapists and occupational therapists use serious games with AR or VR technologies as another work tool, especially for rehabilitation practices. The fact that these technologies are also used in Physical Education classes in Brazil indicates that electronic games are available and can be a tool that can contribute to the widespread adoption of exercise as an enjoyable form of recreation.

Keywords: Physical exercise. Physical activity. Virtual reality. Augmented reality.

\section{Resumo}

Introdução: A sociedade atual é influenciada pelas Tecnologias de Informação e Comunicação. Os brinquedos outrora construídos de forma artesanal recebem novas leituras, tornaram-se produtos altamente comercializados e neste contexto os jogos que utilizam as tecnologias de Realidade Aumentada (RA) e Realidade Virtual $(R V)$ estão presentes no cotidiano de crianças, jovens e adultos. Objetivo: Investigar como a Educação Física no Brasil vem se apropriando dos jogos de RA e RV em seu benefício. Materiais e métodos: Foram incluídos apenas estudos que envolveram exercício físico ou atividade física com o uso dos jogos com $R A$ ou $R V$. A busca ocorreu nas bases de dados Biblioteca Virtual em Saúde (BVS) e Scientific Electronic Library Online (SCiELO), utilizando os termos "realidade aumentada", "realidade virtual", exergames, Wii ou "serious games". Resultados: 19 artigos foram incluídos na revisão sistemática e o instrumento mais utilizado foi o Nintendo ${ }^{\circledR}$ Wii com mais de 25 tipos diferentes de jogos. Em relação aos sujeitos da pesquisa, foram quatro estudos com indivíduos hígidos (média $=65,7$ ), três examinaram pacientes com doença de Parkinson (média = 18,0), três com idosas (média $=7,7)$ e dois com lesão decorrente de acidente vascular encefálico (média $=6,0)$. Conclusão: Os jogos que utilizam RA e RV estão presentes como ferramenta de trabalho de fisioterapeutas e terapeutas ocupacionais, utilizados principalmente para reabilitação e a produção na Educação Física no Brasil sinaliza que os jogos eletrônicos estão disponíveis e podem ser uma ferramenta com poder de contribuir com a adoção do exercício como uma forma prazerosa de lazer.

Palavras-chave: Exercício físico. Atividade física. Realidade virtual. Realidade aumentada.

\section{Introduction}

Every story is a construction of humanity, which involves social, cultural and economic factors. Thus, the story of games started early in labor relations history, with the process of the creation and use of tools for this purpose. Play activity, understood as a free activity or using rules, has a symbolic and functional role. Throughout the game, children come into contact with signs produced by the culture to which they belong, because the play activity is structured according to the cultural meaning systems of their group. Language, as a mediator of culture, makes it possible for us to understand play from a historical-cultural point of view: Language allows children to operate in the absence of objects, to generalize and categorize the objects with which they come into contact, and communication ensures the conservation and transmission of information and experiences (1).

In Brazil, Kishimoto (2-4) and João Batista Freire (5) stand out in the research of games, toys and play activity, evidencing historical aspects, gender relations, and their use as a resource in teaching and learning processes. They also try to elucidate these activities in the educational context.

Physical Education has widened its area of expertise, both in the formal context (schools) and in various perspectives of the informal context (training) (6). This area of expertise is recognized as a promoter of health, and the available technological resources can aid in the creation of strategies to promote the adoption of an active lifestyle (7). In this sense, computer science becomes a versatile tool that can be used to improve human performance by assisting in 
the implementation of intervention routines in physical education, from assessment to prescription. Thus, technological advances exert a profound modifying effect on the organizational processes of contemporary society (8).

Toys once built by hand - any pieces of wood, cloth or paper that were transformed into toys - have been reinterpreted and have become highly commercialized products. In this context, computers and video games have started to be used as toys $(9,10)$. Kings and Cavichiolli (11) assert that the video game industry is considered the world's biggest entertainment industry. The authors report that, in 2001, the gaming industry earned US $\$ 21$ billion, three times more than the Hollywood film industry, and it has a projected growth of $20.1 \%$ per annum in the next five years.

Games and toys have changed in structure, time and space. They have been transferred to other environments using the Internet and information and communication technology (ICT) tools. They can be explored through a virtual system in real time, and players can interact with people located in different places. A web of virtual personal relationships is formed, and in this context, people communicate, get informed, play and have fun (12).

Computerized products, which appeared as video games in the $80 \mathrm{~s}$ and were controlled by joysticks, mouse pads, gamepads or computer keys, have now gained new forms: They are controlled by player movements and make use of innovative peripherals, such as electronic dance pads, motion platforms, exercise bikes, haptic devices and motion-tracking cameras (13).

Video game players (of dance or sports games) are motivated to produce larger movements and abandon a sitting position in front of the television or computer in order to be able to play these interactive games, which are activated through body movements.

These interaction techniques, which have been made available by Virtual Reality (VR) and Augmented Reality (AR) technologies, allow the simulation of everyday situations in real life, as well as safe involvement in behaviors and challenges (14); in addition, they are interesting and motivating to the participant (15).

VR (three-dimensionally) simulates the real world by using computer graphics concepts. It thus allows an intuitive interaction using devices such as Head Mounted Displays (HMDs), data gloves or the user's own body (14). In terms of its functionality, VR is a simulation that uses the computer to create a vision of the real world and respond instantly when user motion is detected (16). Therefore, in a VR game, the environment is predominantly "virtual", and the user feels "inserted" into this context.

In the case of AR, the real world environment is used to visualize and interact with virtual objects, giving the illusion that the virtual world and the real world coexist. Unlike Virtual Reality, which "transports" users into a virtual environment, Augmented Reality keeps users in their physical environment and transports the virtual environment into the users' space by means of a technological device such as a video camera that captures users' movements and a multimedia projector that presents the virtual objects (or a video monitor screen). Thus, AR is expected to allow users to interact with virtual content in a natural and intuitive manner with no need for adaptation or training (14).

The evolution of these two knowledge areas Physical Education and Information and Communication Technology (ICT) - provides us with facts that lead us to investigate how Physical Education professionals in Brazil have been making use of AR and VR games (designed with the purpose of entertaining through exercise, sports and dance) and Information and Communication Technology to benefit their work. We also investigated their attitudes toward these technological tools, their use in daily work, and future possibilities for the profession in the use of new entertainment technologies.

\section{Methods}

Data sources and search strategies

We searched the databases of Virtual Health Library (VHL) and Scientific Electronic Library Online (SciELO) using the words augmented reality, virtual reality, exergames, Wii and serious games (Figure 1).

We only selected empirical articles addressing the use of virtual reality (VR) or augmented reality (AR) in physical activity or exercise. All of the studies found were assessed by their titles and abstracts, and the relevant articles were read in full.

Duplicate articles were excluded, and all articles that met the inclusion and exclusion criteria described in Table 1 were included in the systematic review. 


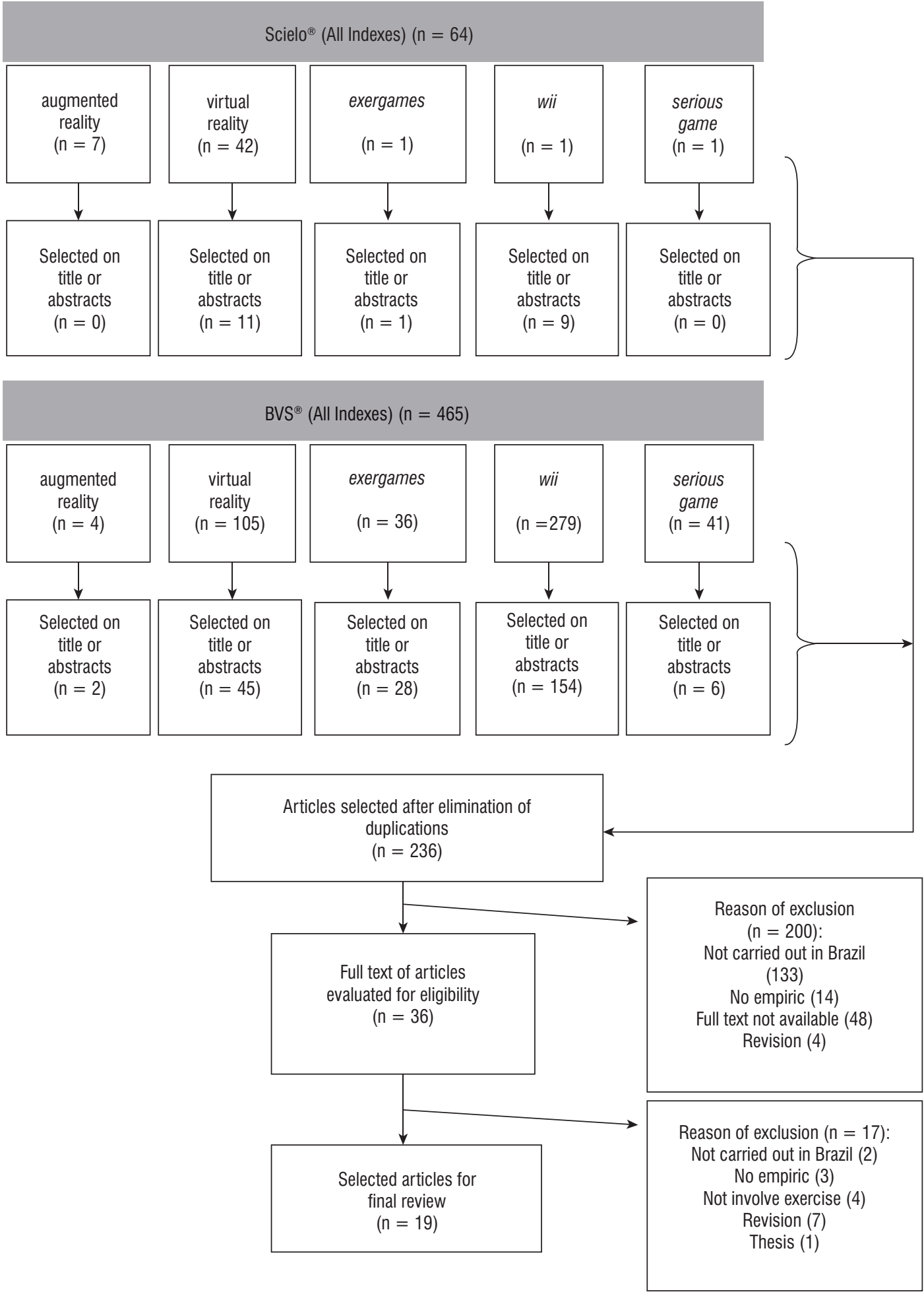

Figure 1 - Flow chart of the search in the databases Virtual Health Library (VHL) (http://www.bvsalud.org) and Scientific Electronic Library Online (SciELO) 
Table 1 - Inclusion and exclusion criteria used to select articles retrieved from the Virtual Health Library (http://www. bvsalud.org) and the Scientific Electronic Library Online (SciELO)

\begin{tabular}{l}
\hline \multicolumn{1}{c}{ Inclusion } \\
\hline Study conducted in Brazil \\
Used AR or VR technologies in physical activity or exercise training \\
Proposed the use of some kind of AR or VR technology in physical activity or exercise training \\
Proposed some AR or VR use for rehabilitation through physical activity or exercise training \\
\hline \multicolumn{1}{c}{ Exclusion } \\
\hline Theses and dissertations \\
Did not use AR or VR \\
Used VR games commanded by mouse or keyboard only \\
\hline
\end{tabular}

Note: $A R=$ Augmented Reality; VR= Virtual Reality.

Access to the full text of articles allowed us to identify where the papers had been published. We only selected the studies that had been conducted in Brazil. When information on the country where the study had been conducted could not be abstracted from the description of the subjects, the authors' affiliation was used to determine the country to which a publication was to be attributed.

The decision to investigate only studies conducted in Brazil was due to the fact that the stateof-the-art research on the use of technology to promote health and physical activity has been reported in systematic reviews worldwide conducted in the main databases, such as Cochrane Library, PsychInfo, PubMed, Web of Science, and SPORTDiscus (17); and PsycInfo, Medline, and PsycArticles (18). Thus, an updated view of the topic is already available for other countries. In addition, Nunes et al. (19) allege that there are several Brazilian research groups that are developing applications with VR and conducting research on a wide range of topics. We tried to find these studies conducted in Brazil.

The studies were first assessed by title and then by abstract. All of those which addressed body movements with the use of interactive games were included in the first sample. We selected all of the articles that addressed the use of AR or VR technologies in physical activity or exercise training. When the title or abstract did not contain enough information to make a decision to include the article in the sample, the full text was analyzed. We paid special attention to the identification of the method used, the study site (in Brazil or abroad) and the proposed activity using AR or VR.

\section{Results}

We selected 19 articles from a total of 465 papers found in the databases Virtual Health Library (VHL) and Scientific Electronic Library Online (SciELO). We accessed the databases to identify the content, title, and publication data of each of the articles. The articles that met the inclusion criteria described in Table 1 were selected for this review.

Only articles addressing physical activity and associated with the use of augmented reality (AR) or virtual reality (VR) were selected. The final sample was constituted of 19 studies (Table 2).

The most frequently used device was the Nintendo ${ }^{\circledR}$ Wii Fit $(n=13)$, which offers several different kinds of games, followed by the Balance Rehabilitation Unit - BRU ${ }^{\mathrm{TM}}(\mathrm{n}=4)$. Cacau et al. (20) did not mention what device was used in their study and Damasceno, Lamounier Junior and Cardoso (28) used the MoCap interface, which organizes the data produced and presents the user with a variation of the motion disability measured at the beginning and end of each therapy session. Other types of information offered by the interface include average strength, speed and exercise time. 


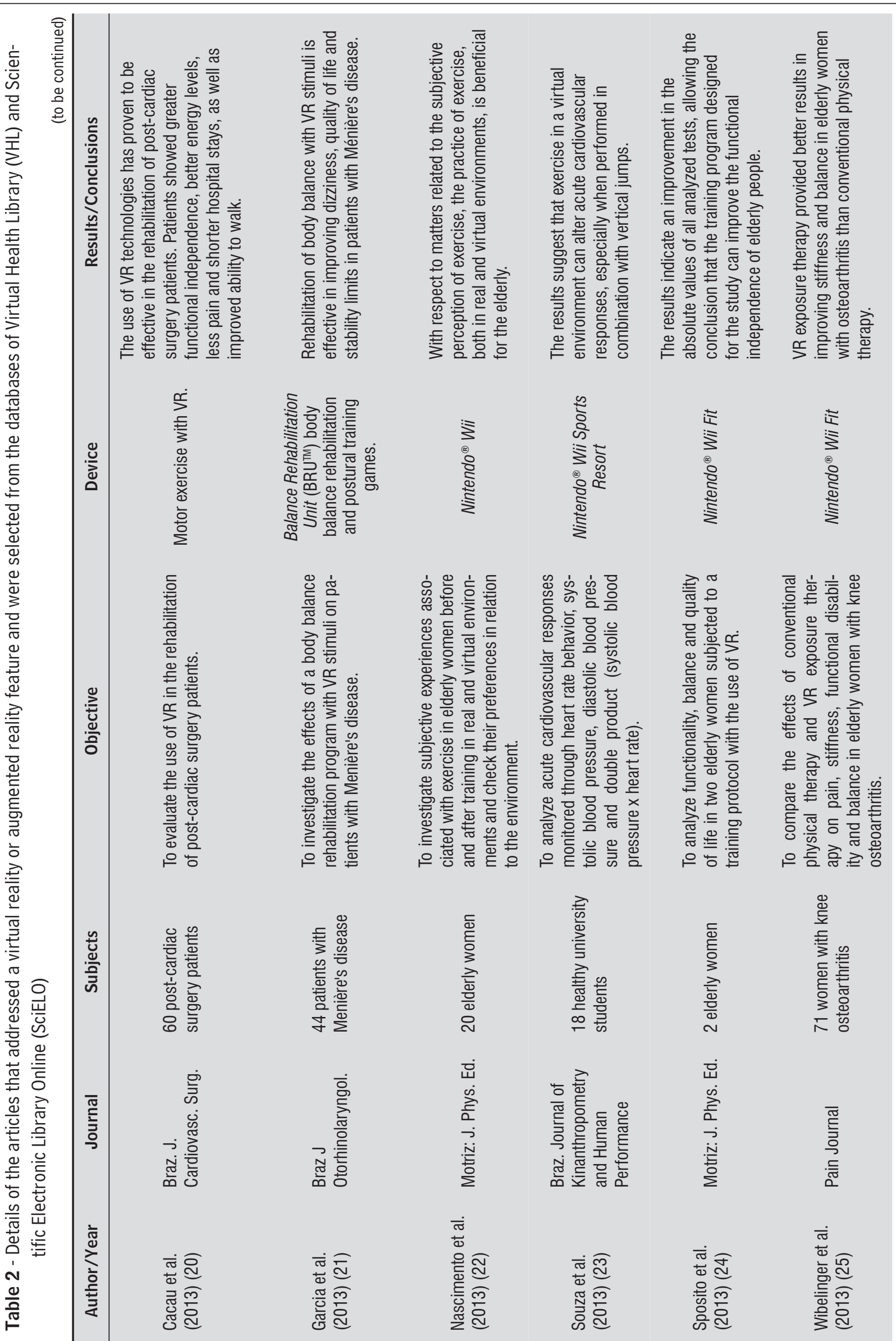




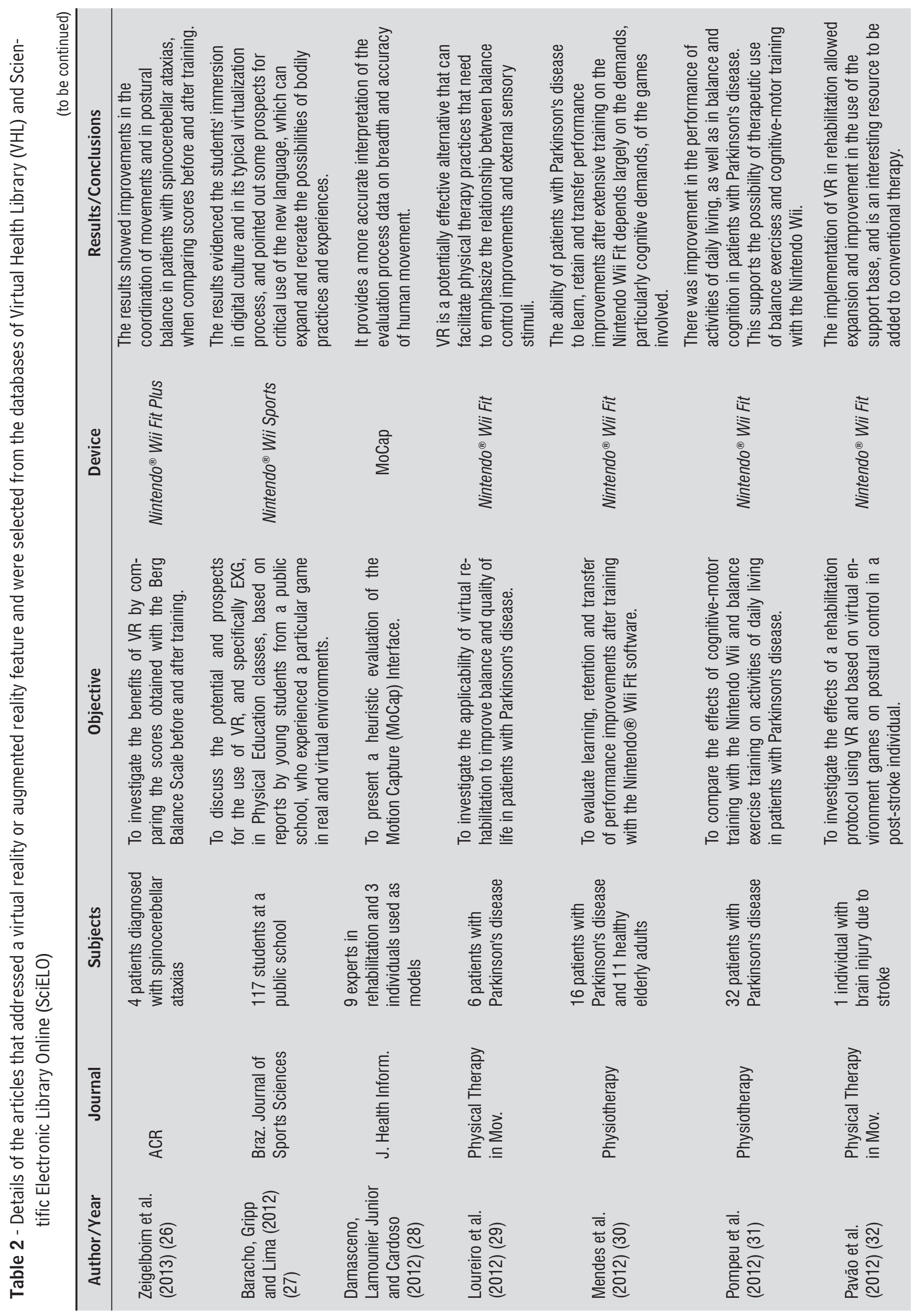




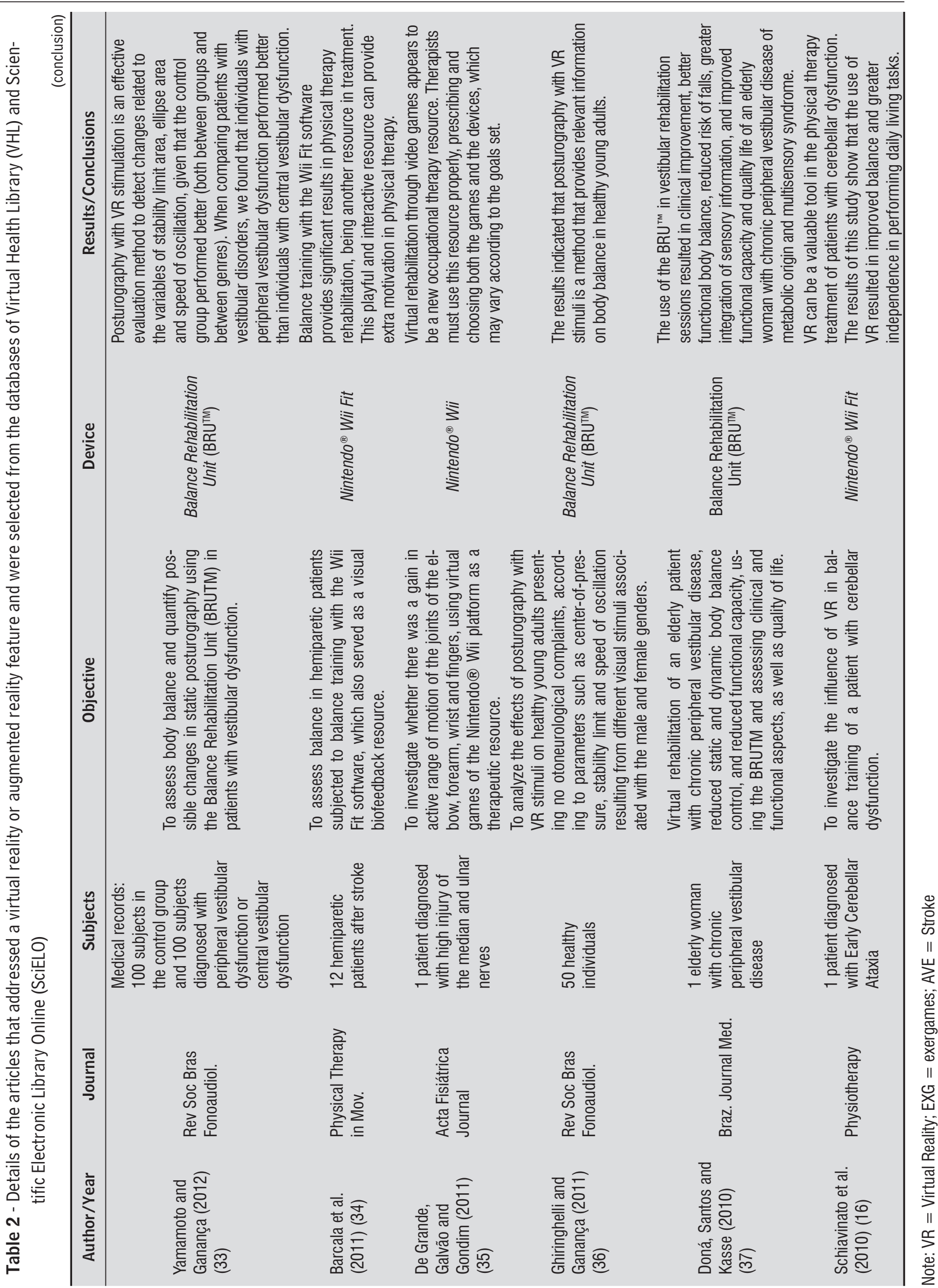


The Nintendo ${ }^{\circledR}$ Wii is a home video game console that uses a wireless motion-sensitive controller to detect user movements and uses them to control the game (22). The latest device offered by the Nintendo ${ }^{\circledR}$ Wii is the Balance Board, which requires individuals to constantly change their standing posture and assesses their ability to control environmental stimuli by analyzing the induced changes in the standing posture (34). The following video games were used: Just Dance I (22); Sports Resort with basketball $(23,35)$, baseball (38) or boxing (35); Deep Breathing (24); Half Moon (24, 29); Warrior (24); Table Tilt $(24,25$, 29-31); Soccer (24); Basic Run (24, 30, 31); Basic Step (24, 30, 31); Hula Hoop (24); Single Leg Extension (24, 30, 31); Torso Twists (24, 31); Lunge (24); Balance Games (25); Penguin Slide (16, 25, 29-31); Ski Slalom $(25,29)$; Soccer Heading $(25,29-31)$; Bird's-Eye Bull'sEye (26); Big Top Juggling (26); Tightrope Walk (29); Tilt City (30, 31); Obstacle Course (30, 31); Rhythm Parade (30, 31); TTW (30); Food Network (35) and Balance Bubble (16). Pavão et al. (32) investigated six balance games included in the Wii Fit software, but did not mention which ones.

The Balance Rehabilitation Unit (BRU ${ }^{\mathrm{TM}}$ ) is a device that uses the transmission of virtual images seen through 3D glasses - to recreate situations that cause dizziness. It comprises a computer with the test software, a safety metal structure, a security holder with handles and a belt, a strength platform measuring $40 \mathrm{~cm} \times 40 \mathrm{~cm}$, virtual reality glasses, an accelerometer and a foam cushion. Three modules are included: posturography, body balance rehabilitation and postural training games (21). This system makes it possible to train the different movements and oculomotor reflexes involved in the maintenance of body-balance in a controlled manner, by using a variety of visual stimuli modified according to frequency, depth perception, direction and movement speed (37).

Barcala et al. (34) performed a comparative analysis of balance in 12 hemiparetic patients by conducting 30-minute sessions of conventional physical therapy and 30-minute sessions of balance exercises using the Wii Fit software, which offers a visual biofeedback resource. The sessions were conducted twice weekly. The authors explained that the Nintendo ${ }^{\circledR}$ Wii Balance Board requires individuals to constantly change their standing posture and assesses their ability to control environmental stimuli. The results that were found were significant, and the interactive device that was used motivated individuals to participate in the physical therapy sessions.

Three studies investigated the use of several Nintendo Wii games in patients with Parkinson's disease (29-31). The postural and balance changes presented by patients with this disease are important parameters used by physical therapists in choosing the best therapies for these patients (29). All of the studies showed results that support the use of VR as a new therapeutic tool, because it increases motivation and adherence to long-term rehabilitation processes.

Nascimento et al. (22) and Sposito et al. (24) used the Nintendo Wii software in elderly women. They found improvements in different psychological factors and asserted that it is a device that can be used during leisure time and encourages the practice of physical exercise.

Souza et al. (23) considered the exercises performed with the Nintendo Wii Sports Resort basketball game to be of mild to moderate intensity. According to the authors, virtual games could help improve and maintain cardiorespiratory fitness in healthy university students, and they should be seen as an auxiliary tool to reduce monotony and increase entertainment and adherence to physical activity, always with the guidance of a professional instructor. Baracho, Gripp and Lima (38) compared the perceptions of students from a public school when playing a baseball game in a virtual and in a real environment. The authors concluded that VR games contributed in a direct way to the practice of physical education in schools, because it increased students' motivation and participation during classes. However, they say that physical education teachers should not consider virtual games as an immediate substitute for real games, but rather as a challenge that involves the assimilation of a new language, which expands and re-creates the possibilities of corporal practices in cyberspace.

The other studies used the Nintendo Wii during physical therapy sessions conducted with women with knee osteoarthritis (25), patients with spinocerebellar ataxias (26), as well as patients with brain damage due to stroke (32), patients diagnosed with high injury of the median and ulnar nerves (35) and patients diagnosed with Early Cerebellar Ataxia (16). All of these studies reported positive results with the use of VR games.

According Doná, Santos and Kasse (37), the use of the Balance Rehabilitation Unit (BRU ${ }^{\mathrm{TM}}$ ) in 
vestibular rehabilitation sessions resulted in clinical improvement, better functional body balance, reduced risk of falls, greater integration of sensory information, and improved the functional capacity and quality of life of an elderly woman with chronic peripheral vestibular disease of metabolic origin and multisensory syndrome.

Ghiringhelli and Ganança (36) found relevant results in posturography with VR stimuli using the BRU ${ }^{\mathrm{TM}}$ platform in young adults with balance disorders. Data collection was conducted with 50 healthy young adults presenting no otoneurological complaints, according to parameters such as center-of-pressure, stability limit and speed of oscillation resulting from different visual stimuli associated with the male and female genders.

The BRU ${ }^{\mathrm{TM}}$ platform was also used by Garcia et al. (21) to assess and rehabilitate patients with dizziness and associated symptoms. When compared to the control group, the experimental group, which participated in the rehabilitation program with VR, showed improvements in dizziness and quality of life, as well as an increase in stability limit areas and an improved ability to move their bodies and maintain balance without altering the support base. Yamamoto and Ganança (33) concluded that the $\mathrm{BRU}^{\mathrm{TM}}$ is an effective method to assess the stability limit area, ellipse area and speed of oscillation in patients with vestibular dysfunction.

\section{Discussion}

The phenomenal growth of Information and Communication Technologies and the growing use of video games in the everyday lives of people from various age groups is noteworthy. According to the studies reviewed in this article, video games and software using virtual reality (VR) and augmented reality (AR) motivate physical activity and contribute to improving the health of patients who are participating in rehabilitation treatment programs.

Some studies also evidenced the use of video games with VR effects in physical education classes. This fact seems to indicate that health professionals are applying the resources and knowledge acquired from these technologies to their scientific studies, as well as in practice with their students and clients. These technologies allow the practice of physical activities through sports, sport fights and dance, and they are readily available on market shelves for popular consumption.

A review by Sousa (39) investigated the use of the Nintendo ${ }^{\circledR}$ Wii software as a therapeutic tool and the risk factors associated with it. The author suggests the use of these devices in the rehabilitation of patients with obesity or motor or postural dysfunction.

These resources and technologies are in the market and should be tested and used by health professionals in their everyday work. This was evidenced by all of the studies reviewed, which investigated different kinds of video games. However, there is a need for further collective research involving a variety of health professionals in order to create and develop proposals for this market. This would probably aid in the acceptance and use of AR and VR technologies as health tools and increase their degree of reliability, because such technologies would be designed and monitored by experts who know the needs of patients.

The studies reviewed have shown that video games with AR and VR effects possess playful elements that motivate, encourage, and provide pleasant, as well as learning moments. However, in order for these games to be safely used in gyms, schools and clinics, further studies are needed to test their performance in a significant number of subjects, corroborate the results reported herein and provide other results that guide professional practices.

The training of professional physical educators can produce knowledge that enables the qualification of activities using AR and VR. In addition, it may find results suggesting that the combination of VR and $A R$ and exercise may result in some psychological benefits, as well as in increased feelings of energy and pleasure, and reduced levels of perceived tiredness $(23,40)$. Moreover, given the policy for the inclusion of people with disabilities in mainstream schools, these technologies could be used as an aid for physical education teachers, who often have difficulties in involving these students in the proposed activities (38).

There is a broad field for investigation. Nevertheless, it is necessary for health professionals to break their resistance to these technologies, to get to know these games and to apply them to their daily work, in order to benefit from their potential to motivate the practice of physical activities.

To think about the profession is to design the future. We live in a time when professionals must be 
creative, innovative and possess a deep knowledge of their field. Thus, we must envision and develop gyms, clinics, schools and leisure facilities that can use these resources in order to improve daily practice. In fact, going against the available technologies means not believing that it is possible to work smoothly with them.

Professional physical educators have always had to deal with a multiplicity of tools and apparatuses, such as balls, timers, fitness equipment, etc. Video games with AR or VR effects should be seen as new equipment that is available on the market for use in their daily work. Therefore, it is necessary to expand and create new experiences.

\section{Conclusion}

One cannot deny that Information and Communication Technologies are constantly changing our way of being in the world. And this consequently changes our culture of body movements. We must stay vigilant to keep pace with these changes and to analyze them critically.

The studies reviewed have shown that video games using virtual reality (VR) and augmented reality (AR) effects are already being used as an everyday working tool by physical therapists and occupational therapists in the rehabilitation of patients. Further, studies conducted in physical education settings in Brazil have found positive results associated with the use of such technologies in exercise and physical activity practices.

The involvement of health professionals in the creation and testing of games with AR and VR in significant patient populations is an emerging need, which will enable scholars to improve the reliability of research findings.

We envisage the possibility of future changes in the attitudes of teachers as mediators of and experts in physical activity who are able to guide and motivate their students by using, researching and creating tools (together with other professionals) that give them support and speak the language of contemporaneity. This movement can be developed in research groups and through the possibility for this content to become a part of professional training.

This study indicates that video games are available and can be a tool that may contribute to the adoption of exercise as an enjoyable form of recreation. We hope that this study can provide useful guidance about this wide research field for educators, professionals and researchers in the fields of Physical Education and Physical Therapy, as well as for video game designers.

\section{Acknowledgments}

Santa Catarina Pos-Graduate Program UNIEDU.

\section{References}

1. Alves AMP, Gnoato G. O brincar e a cultura: jogos e brincadeiras na cidade de Morretes na década de 1960. Psicol Estud. 2003;8(1):111-7.

2. Kishimoto TM. O brinquedo na educação: considerações históricas. Série Idéias [Internet]. 1995; 7:39-45.

3. Kishimoto TM, Ono AT. Brinquedo, gênero e educação na brinquedoteca. Pro-Posições. 2008; 19: 209-23.

4. Kishimoto TM, Pinazza MA, Morgado RdFC, Toyofuki KR. Jogo e letramento: crianças de 6 anos no ensino fundamental. Educ Pesqui. 2011; $37: 191-210$.

5. Freire JB, Feijó ATM. Oficinas do jogo: uma abordagem pedagógica transdisciplinar nas séries iniciais do ensino fundamental. Rev Bras Ciênc Esporte. 2008;29(3):107-21.

6. Proni MW. Universidade, profissão Educação Física e o mercado de trabalho. Motriz: rev educ fis. 2010; 16(3):788-98.

7. Figueira Júnior AJ. Potencial da mídia e tecnologias aplicadas no mecanismo de mudança de comportamento, através de programas de intervençäo de atividade física. Rev bras cienc mov. 2000; 8(3): 39-46.

8. Abrahão JI, Pinho DLM. As transformações do trabalho e desafios teórico-metodológicos da Ergonomia. Estud psicol (Natal). 2002;7(spe):45-52.

9. Aranha G. 0 processo de consolidação dos jogos eletrônicos como instrumento de comunicação e de construção de conhecimento. Cienc Cogn. 2004; 3:21-62. 
10. Meira AM. Benjamin, os brinquedos e a infância contemporânea. Psicol Soc. 2003;15(2):74-87.

11. Almeida LJR, Cavichiolli FR. Jogos eletrônicos e a busca da excitação. Movimento. 2008;14(3):163-83.

12. Araújo BMR, Freitas CMSM, Caminha IO, Silva PPC. Virtualização esportiva e os novos paradigmas para o movimento humano. Motriz: Rev Educ Fis. 2011;17(4):600-9.

13. Papastergiou M. Exploring the potential of computer and video games for health and physical education: a literature review. Comput Educ. 2009; 53(3):603-22.

14. Hounsell MS, Xavier DC, Crocetta TB, Andrade A. Análise do controle motor com interações baseadas em dispositivos convencionais e realidade aumentada. RITA. 2010;17(2):154-73.

15. Barilli ECVC, Ebecken NFF, Cunha GG. A tecnologia de realidade virtual como recurso para formação em saúde pública à distância: uma aplicação para a aprendizagem dos procedimentos antropométricos. Cien Sau Colet. 2011;16:1247-56.

16. Schiavinato AM, Baldan C, Melatto L, Lima LS. Influência do Wii Fit no equilíbrio de paciente com disfunção cerebelar: estudo de caso [Influence of the Wii Fit on the balance of cerebellar dysfunction patient: case study]. J Health Sci Inst. 2010;28(1).

17. Peng W, Crouse JC, Lin JH. Using active video games for physical activity promotion: a systematic review of the current state of research. Health Educ Behav. 2013;40(2):171-92.

18. Ferrer-Garcia M, Gutiérrez-Maldonado J, Riva G. Virtual reality based treatments in eating disorders and obesity: a review. J Contemp Psychother. 2013; 43(4):207-21.

19. Nunes FLS, Costa RMEM, Machado LS, Moraes RM. Realidade virtual para saúde no Brasil: conceitos, desafios e oportunidades [Virtual reality for health care in Brazil: concepts, challenges and opportunities]. Rev Bras Eng Biomed. 2011;27(4):243-58.

20. Cacau LA, Oliveira GU, Maynard LG, de Araújo Filho AA, da Silva WM, Cerqueria Neto ML, et al. The use of the virtual reality as intervention tool in the postoperative of cardiac surgery. Rev Bras Cir Cardiovasc. 2013;28(2):281-9.
21. Garcia AP, Ganança MM, Cusin FS, Tomaz A, Ganança FF, Caovilla HH. Reabilitação vestibular com realidade virtual na doença de Ménière [Vestibular rehabilitation with virtual reality in Ménière's disease]. Braz J Otorhinolaryngol. 2013;79(3):366-74.

22. Nascimento AM, Rodrigues NH, Andrade EF, Rogatto GP, Schwartz GM, Valim-Rogatto PC. Experiência subjetiva de idosas durante exercício em ambiente virtual [Subjective experience of older women during exercise in virtual condition]. Motriz: Rev Educ Fis. 2013;19(3supl):68-75.

23. Souza RA, Cruz LG, Carvalho PS, Silva FF, Carvalho WRG. Respostas cardiovasculares agudas em ambiente virtualmente simulado pelo Nintendo Wii [Acute cardiovascular responses in a virtual environment simulated by Nintendo Wii]. Rev Bras Cineantropom Desempenho Hum. 2013;15(1):60-70.

24. Sposito LAC, Portela ER, Bueno EFP, Carvalho WRGd, Silva FFd, Souza RAd. Experiência de treinamento com Nintendo Wii sobre a funcionalidade, equilíbrio e qualidade de vida de idosas [Training experience with Nintendo Wii on functionality, balance and quality of life in elderly]. Motriz: Rev Educ Fis. 2013; 19(2):532-40.

25. Wibelinger LM, Batista JS, Vidmar MF, Kayser B, Pasqualotti A, Schneider RH. Efeitos da fisioterapia convencional e da wiiterapia na dor e capacidade funcional de mulheres idosas com osteoartrite de joelho [Effects of conventional physiotherapy and wii therapy on pain and functional capacity of elderly women with knee osteoarthritis]. Rev Dor. 2013;14(3):196-9.

26. Zeigelboim BS, Souza SD, Mengelberg H, Teive HAG, Liberalesso PBN. Reabilitação vestibular com realidade virtual na ataxia espinocerebelar [Vestibular rehabilitation with virtual reality in spinocerebellar ataxia]. Audiol Commun Res. 2013;18(2):143-7.

27. Baracho AFO, Gripp FJ, Lima MR. Os exergames e a educação física escolar na cultura digital [Exergames and the school physical education in the digital culture]. Rev Bras Ciênc Esporte. 2012;34(1):111-26.

28. Damasceno EF, Lamounier Junior EA, Cardoso A. Uma avaliação heurística sobre um sistema de captura de movimentos em realidade aumentada [An heuristic evaluation of augmented reality motion capture system]. J Health Inform. 2012;4(3). 
29. Loureiro APC, Ribas CG, Zotz TGG, Chen R, Ribas F. Viabilidade da terapia virtual na reabilitação de pacientes com doença de Parkinson: estudo-piloto [Feasibility of virtual therapy in rehabilitation of Parkinson's disease patients: pilot study]. Fisioter Mov. 2012;25(3):659-66.

30. Mendes FAS, Pompeu JE, Lobo AM, da Silva KG, Oliveira $\mathrm{TP}$, Zomignani AP, et al. Motor learning, retention and transfer after virtual - reality-based training in Parkinson's disease - effect of motor and cognitive demands of games: a longitudinal, controlled clinical study. Physiotherapy. 2012;98(3):217-23.

31. Pompeu JE, Mendes FAS, Silva KG, Lobo AM, Oliveira TP, Zomignani AP, et al. Effect of Nintendo Wii ${ }^{\mathrm{TM}}$ based motor and cognitive training on activities of daily living in patients with Parkinson's disease: a randomised clinical trial. Physiotherapy. 2012;98(3):196-204.

32. Pavão SL, Sousa NVC, Oliveira CM, Castro PCG, Santos MCM. 0 ambiente virtual como interface na reabilitação pós-AVE: relato de caso [Virtual environment as an interface device in post-stroke rehabilitation: case report]. Fisioter mov. 2013;26(2):455-62.

33. Yamamoto MEI, Ganança CF. Posturografia com estímulos de realidade virtual nas diferentes disfunções vestibulares [Posturography with virtual reality stimuli in different vestibular dysfunctions]. Rev Soc Bras Fonoaudiol. 2012;17(1):54-60.

34. Barcala L, Colella F, Araujo MC, Salgado ASI, Oliveira CS. Análise do equilíbrio em pacientes hemiparéticos após o treino com o programa Wii Fit. Fisioter mov. 2011;24:337-43.

35. De Grande AAB, Galvão FRO, Gondim LCA. Reabilitação virtual através do videogame: relato de caso no tratamento de um paciente com lesão alta dos nervos mediano e ulnar [Virtual rehabilitation using video games: a case report of the treatment of a patient with high median and high ulnar nerve lesions]. Acta Fisiatr. 2011;18(3).
36. Ghiringhelli R, Ganança CF. Posturografia com estímulos de realidade virtual em adultos jovens sem alterações do equilíbrio corporal [Posturography with virtual reality stimulations in normal young adults with no balance complaints]. J Soc Bras Fonoaudiol. 2011;23(3):264-70.

37. Doná F, Santos FBC, Kasse CA. Reabilitação do equilíbrio corporal por realidade virtual em uma idosa com vestibulopatia periférica crônica [Balance body rehabilitation with virtual reality in an elderly patient with chronic vestibular disorder]. Rev Bras Med. 2010;67(supl.3).

38. Baracho AFO, Gripp FJ, Lima MR. Os exergames e a educação física escolar na cultura digital [Exergames and the school physical education in the digital culture]. Rev Bras Ciênc Esporte. 2012;34(1):111-26.

39. Sousa FH. Uma revisão bibliográfica sobre a utilização do Nintendo ${ }^{\circledR}$ Wii como instrumento terapêutico e seus fatores de risco. Rev Espaço Acadêmico. 2011;123:155-60.

40. Plante TG, Aldridge A, Bogden R, Hanelin C. Might virtual reality promote the mood benefits of exercise? Comput Human Behav. 2003;19(4):495-509.

Received: 06/05/2014

Recebido: 05/06/2014

Approved: 04/27/2015 Aprovado: 27/04/2015 
